\title{
Archaeobotanical reconstructions of field habitats and crops: the grange in Pomorzany near Kutno, $18^{\text {th }} / 19^{\text {th }} \mathrm{c}$.
}

\author{
Joanna Koszałka* \& Joanna Ewa Strzelczyk
}

Institute for Archaeology and Ethnology, Polish Academy of Sciences, Rubież 46, 61-612 Poznań, Poland

* corresponding author (e-mail: joanna.koszalka@iaepan.poznan.pl)

\begin{abstract}
The paper presents the results of research of plant macrofossils from the grain deposit deriving from the $18^{\text {th }} / 19^{\text {th }}$ centuries. The analysed material included 24760 diaspores representing 73 taxa. The majority were cultivated cereal crop species, and there was also abundance of accompanying segetal weed species. About $95 \%$ of the gathered crop material was Secale cereale. Another important crop was Hordeum vulgare and there were also some remains of Avena sativa, Triticum aestivum, Fagopyrum esculentum. Cannabis sativa and Linum usitatissimum were found as well. Weeds competing with these crops were, among others, the following species: Agrostemma githago, Raphanus raphanistrum, Apera spica-venti, Bromus secalinus, Centaurea cyanus, Spergula arvensis, Thlaspi arvense, Viola arvensis/tricolor, Fallopia convolvulus, Polygonum persicaria, Mentha arvensis, Anthemis arvensis, Papaver rhoeas, Rumex acetosella, Scleranthus annuus, Aphanes arvensis, Setaria pumila, Setaria viridis/verticilata. Extremely large presence of wild plant diaspores in the material allowed conducting economic and environmental interpretations. Reconstruction methods applied, used primarily in the case of macroremains from granaries, were fully applicable to the analysed plant residues. Weed species composition in the analysed material showed that they were mostly typical for the main winter crop. Some amount of species typical for other habitats were also found and they probably came from the near-by rye field. The presence of perennial diaspores indicated that the field was probably set aside.
\end{abstract}

Key words: plant macrofossils, archaeobotany, rye, crop weeds

\section{Introduction}

During archaeological excavations conducted in years 2003-2005 in a former grange in Pomorzany, a deposit of charred grain was discovered. It was located in a small residential building associated with the latest phase of building the farm $\left(17^{\text {th }}-18^{\text {th }} \mathrm{c}\right.$. $)$, situated in the neighborhood of farm buildings (Fig. 1). The house was designed for serfs. It was destroyed by fire and leveled, most likely, at the beginning of the $19^{\text {th }}$ century (Maik 2013).

Cereal residues were found in a burning lens about $20-30 \mathrm{~cm}$ thick, located in the remains of an old threshing floor at the attic of the building. The grains were put through $\mathrm{C} 14$ analysis which dated them to the year 1650 , with $60 \%$ of data that indicated years 1800 1805 (Goslar 2013). Plant remains were put through archaeobotanical analysis which aimed at reconstructing the composition of the crop and the weed flora from fields cultivated by the farm people. On the basis of the ecological requirements of individual species and their occurrence in modern and relict plantings, the habitat conditions for crops, as well as agronomic practices used in the past can be stated with high probability. For the attempt to reconstruct past environments from modern periods it is suitable to use the principle of uniformitarism which was adopted for paleoecological analyses in the course of several scientific studies (Wasylikowa 1983; Lityńska-Zajac \& Wasylikowa 2005). In our work, we used methods of reconstructions established in archaeobotany for granary deposits. (cf. Kosina 1977; Koszałka \& Strzelczyk 2006; Badura 2011). As there is little archaeobotanical evidence from the modern period, the results can complement the gap in this research area.

\section{Material and methods}

For the macroremain analysis, a sample of $1000 \mathrm{~cm}^{3}$ was extracted and used. It was sieved with a mesh of 


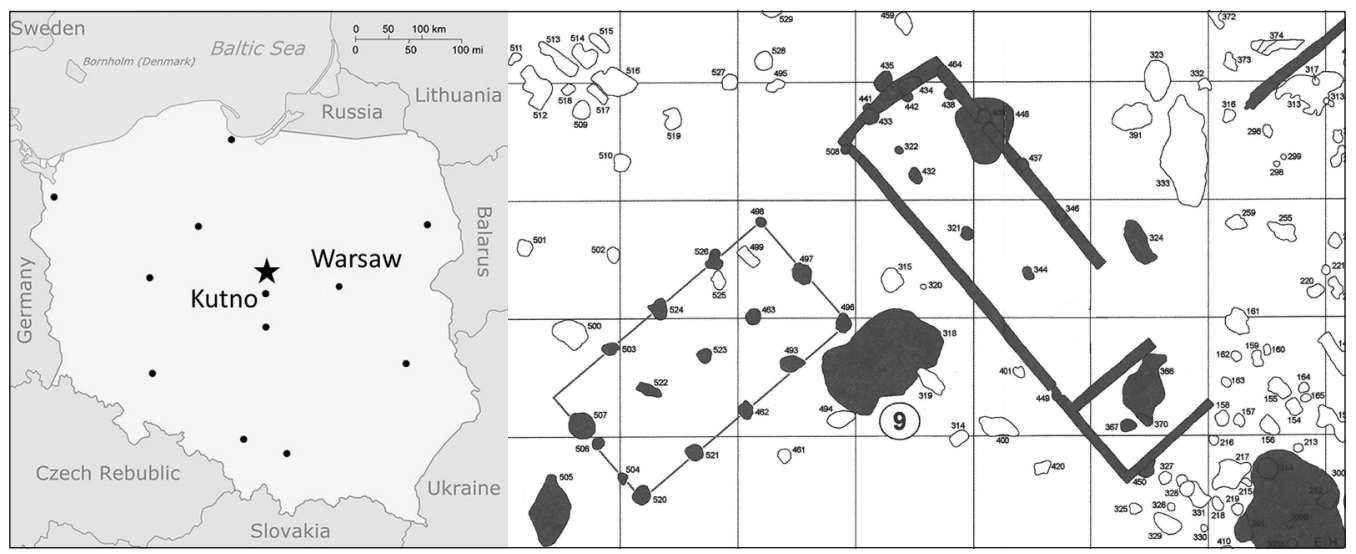

Fig. 1. Location of the Pomorzany site ( $\star$ ) and building no 9

2.0, 0.5 and $0.2 \mathrm{~mm}$. The organic material, divided into fractions, was segregated in small portions under the binocular microscope at 16x magnification. Determinations were made using a dissecting microscope type Nikon SMZ-800. It was based on keys and atlases, and juxtaposed with contemporary carpological collection belonging to the Institute of Archaeology and Ethnology of the Polish Academy of Sciences in Poznan. Botanical nomenclature was cited by Mirek et al. (2002). Geographical-historical classification was based on concepts presented by Zając and Zając (1975) and Jackowiak (1993). Socio-ecological weed groups were defined after Tymrakiewicz (1962) and (Lityńska-Zając 2005). Syntaxonomical nomenclature was adopted according to Matuszkiewicz (2001). The Raunkiaer system and ecological conditions were characterized by ecological indicator values (Zarzycki et al. 2002). The methodology and microscopic laboratory procedures were consistent with those used in archaeobotany (Lityńska-Zając \& Wasylikova 2005).

\section{Results}

The material revealed presence of 24760 diaspores. Among them, there were 23572 specimens of cultivated species - cereals and industrial crops. They were represented by 7 species belonging to 7 genera and 4 families. Family Poaceae was the most numerous in species (4 cereal species). The richest in finds was rye (Secale cereale) (22420 specimens) (Table 1). Another

Table 1. Taxa from the Pomorzany grange deposit

\begin{tabular}{|c|c|c|c|}
\hline Plant name & $\begin{array}{l}\text { No. of } \\
\text { remains }\end{array}$ & G-h group & S-e group \\
\hline \multicolumn{4}{|c|}{ Cultivated species } \\
\hline Avena sativa $\mathrm{L}$. & 45 & & \\
\hline Cannabis sativa $\mathrm{L}$. & 26 & & \\
\hline Fagopyrum esculentum Moench & 344 & & \\
\hline Hordeum vulgare L. & 716 & & \\
\hline Linum usitatissimum L. & 12 & & \\
\hline Secale cereale $\mathrm{L}$. & 22420 & & \\
\hline Triticum aestivum L. s. 1. & 9 & & \\
\hline \multicolumn{4}{|c|}{ Wild plants } \\
\hline Agrostemma githago L. & 10 & $\mathrm{Ar}$ & $C c$ \\
\hline Anagalis arvensis L. & 4 & $\mathrm{Ar}$ & Stel med \\
\hline Apera spica-venti (L.) P. Beauv. & 135 & $\mathrm{Ar}$ & $C c$ \\
\hline Aphanes arvensis L. & 1 & $\mathrm{Ar}$ & $C c$ \\
\hline Anthemis arvensis $\mathrm{L}$. & 28 & $\mathrm{Ar}$ & Stel med \\
\hline Bromus hordeaceus L. & 4 & Ap & Arrhen \\
\hline Bromus secalinus L. & 129 & $\mathrm{Ar}$ & $C c$ \\
\hline Camelina microcarpa Andrz. & 6 & $\mathrm{Ar}$ & $C c$ \\
\hline Capsella bursa-pastoris (L.) Medik. & 4 & $\mathrm{Ar}$ & Stel med \\
\hline Centaurea cyanus L. & 12 & $\mathrm{Ar}$ & $C c$ \\
\hline Centaurea cf. jacea L. & 1 & Ap & Mol-Arr \\
\hline Chenopodium album $\mathrm{L}$. & 148 & Ap & Pol-Chen \\
\hline
\end{tabular}




\begin{tabular}{|c|c|c|c|}
\hline Plant name & $\begin{array}{l}\text { No. of } \\
\text { remains }\end{array}$ & G-h group & S-e group \\
\hline Consolida regalis Gray & 4 & $\mathrm{Ar}$ & $C c$ \\
\hline Coronilla varia $\mathrm{L}$. & 4 & Ap & Trif-Ger \\
\hline Digitaria ischaemum (Schreb.) H. L. Mühl. & 2 & $\mathrm{Ar}$ & Pol-Chen \\
\hline Digitaria sanguinalis (L.) Scop. & 4 & $\mathrm{Ar}$ & Pol-Chen \\
\hline Echinochloa crus-galli (L.) P. Beauv. & 8 & $\mathrm{Ar}$ & Pol-Chen \\
\hline Elymus repens (L.) Gould & 3 & Ap & Stel med \\
\hline cf. Erodium cicutarium (L.) L' Hér & 1 & Ap & Cor, Sed-Scl \\
\hline Euphorbia helioscopia L. & 1 & $\mathrm{Ar}$ & Pol-Chen \\
\hline Fallopia convolvulus (L.) Á. Löve & 20 & $\mathrm{Ar}$ & Stel med \\
\hline Galeopsis ladanum $\mathrm{L}$. & 10 & $\mathrm{Ar}$ & $C c$ \\
\hline Galeopsis tetrahit $\mathrm{L}$. & 8 & Ap & Artemi \\
\hline Galium aparine $\mathrm{L}$. & 2 & Ap & Stel med \\
\hline Galium spurium L. & 6 & $\mathrm{Ar}$ & $C c$ \\
\hline cf. Geranium pusillum Burm. F. ex L. & 2 & $\mathrm{Ar}$ & Pol-Chen \\
\hline Lapsana communis L. s. str. & 2 & Ap & Stel med \\
\hline Lolium temulentum $\mathrm{L}$. & 2 & $\mathrm{Ar}$ & $C c$ \\
\hline Melandrium album (Mill.) Garcke & 2 & Ap & Artemi \\
\hline Mentha arvensis $\mathrm{L}$. & 1 & Ap & Stel med \\
\hline Neslia paniculata (L.) Desv. & 4 & $\mathrm{Ar}$ & $C c$ \\
\hline Papaver rhoeas $\mathrm{L}$. & 2 & $\mathrm{Ar}$ & $C c$ \\
\hline Pimpinella saxifraga $\mathrm{L}$. & 2 & Ap & Fest-Brom \\
\hline Plantago lanceolata L. & 4 & Ap & Mol-Arr \\
\hline Polygonum aviculare L. & 12 & Ap & Stel med, Artemi \\
\hline Polygonum hydropiper L. & 4 & Ap & Bt, Pol-Chen \\
\hline Polygonum lapathifolium L. s. 1. & 14 & $\mathrm{Ar}$ & Pol-Chen, Bt \\
\hline Polygonum lapathifolium L. subsp. lapathifolium & 4 & Ap & Pol-Chen \\
\hline Polygonum lapathifolium L. subsp. pallidum (With.) Fr & 8 & Ap & Pol-Chen, Bt \\
\hline Polygonum minus Huds. & 6 & Ap & Pol-Chen, Bt \\
\hline Polygonum mite Schrank & 8 & Ap & $B t$ \\
\hline Polygonum persicaria $\mathrm{L}$. & 38 & Ap & Stel med \\
\hline Ranunculus repens $\mathrm{L}$. & 1 & Ap & Stel med \\
\hline Raphanus raphanistrum $\mathrm{L}$. & 52 & $\mathrm{Ar}$ & Pol-Chen \\
\hline Rumex acetosa L. & 28 & Ap & Mol-Arr \\
\hline Rumex acetosella L. & 4 & Ap & Coryneph, Arnoser, Dicr-Pin \\
\hline Rumex crispus L. & 4 & Ap & Agr-Rumi, Artemi \\
\hline Rumex obtusifolius L. & 8 & Ap & Artemi, Agr-Rumi \\
\hline Scleranthus annuus L. & 2 & $\mathrm{Ar}$ & $C c$ \\
\hline Setaria pumila (Poir.) Roem. \& Schult & 24 & $\mathrm{Ar}$ & Pol-Chen \\
\hline Sinapis arvensis L. & 4 & $\mathrm{Ar}$ & Stel med \\
\hline Spergula arvensis L. & 64 & $\mathrm{Ar}$ & $C c$ \\
\hline Thlaspi arvense $\mathrm{L}$. & 2 & $\mathrm{Ar}$ & Stel med \\
\hline Valerianella dentata (L.) Pollich & 14 & $\mathrm{Ar}$ & $C c$ \\
\hline Vicia cracca $\mathrm{L}$. & 43 & Ap & Mol-Arr \\
\hline Vicia hirsuta (L.) Gray & 168 & $\mathrm{Ar}$ & $C c$ \\
\hline Vicia sativa $\mathrm{L}$. & 17 & $\mathrm{Ar}$ & Stel med \\
\hline Vicia tetrasperma (L.) Schreb. & 32 & $\mathrm{Ar}$ & $C c$ \\
\hline
\end{tabular}

\begin{tabular}{lc}
\hline \multicolumn{1}{c}{ Other plants } \\
\hline Avena sp. & 8 \\
Brassica sp. & 4 \\
Bromus sp. & 2 \\
Fagopyrum tataricum (L.) Gaertn. & 6 \\
Setaria italica (L.) P. Beauv. & 2 \\
Setaria viridis (L.) P. Beauv./verticillata (L.) P. Beauv. & 4 \\
Vicia sp. & 6 \\
Viola arvensis Murray/tricolor L. s. str. & 5 \\
unidentified spp. & 14 \\
\hline
\end{tabular}

Explanations: G-h group - Geographical-historical group, Ar - archeophytes, Ap - apophytes; S-e group - Socio-ecological group, Agr-Rumi - Agropyrorumicion-crispi, Arnoser-Arnoseridenion minimae, Arrhen-Arrhenatheretalia, Artemi-Artemisietea vulgaris, Bt-Bidention tripartite, Cc - Centauretalia cyani, Coryneph-Corynephoretalia canescentis, Dicr-Pin-Dicrano-Pinion, Fest-Brom-Festuco-Brometea, Mol-Arr-Molinio-Arrhenatheratea,Pol-Chen - Polygono-Chenopodietalia, Stel med - Stellarietea mediae, Trif-Ger-Trifolio-Geranietea sanguinei 


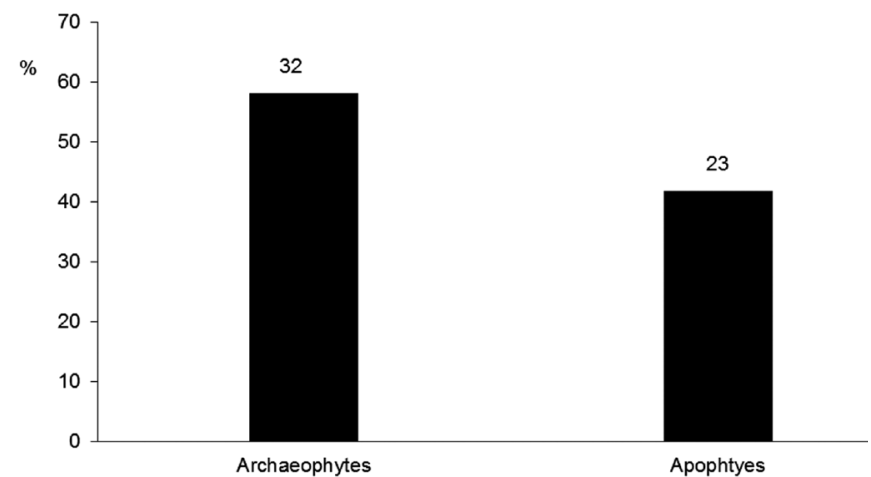

Fig. 2. Geographical-historical spectrum of weeds

important crop was barley (Hordeum vulgare) with the presence of 716 grains. Other species recorded on this site were: oats (Avena sativa) (45 specimens) and wheat (Triticum aestivum) (9 specimens). In addition to the above mentioned cereals, in the collection of the Pomorzany farm, numerous (344 specimens) remains of buckwheat (Fagopyrum esculentum), classified as so-called alleged cereals, because of their similarity to the grain usage were present (Ralski 1957). Other commonly grown species comprised oil plants, such as hemp (Cannabis sativa) (26 fruits) and flax (Linum usitatissimum) (12 seeds).

Wild plants (1174 diaspores) were determined as 67 taxa, including 58 species and 4 genera, more precise determination of which was hindered due to bad condition of finds. Three species could be determined only with probability (signature $c f$. - confer (Lat.) suchlike) and two taxa were determined to types (for example $\mathrm{Se}$ taria viridis/verticillata). Two taxa were determined as subspecies. 14 diaspores could not be determined due to the destruction of their surface. The richest in taxa were Polygonaceae (13 taxa) and Poaceae (13 taxa) families which both included $39 \%$ of weed flora. Geographicalhistorical classification of plants showed that the whole material presented synanthropic flora, with a few percent advantage of archaeophytes over apophytes (Fig. 2). It was weed flora which grew in the most important crop - the rye. The remains of four species prevailed: Vicia hirsuta, Apera spica-venti and Bromus secalinus, belonging to archaeophytes and Chenopodium album, being an apophyte. Raunkiaer spectre of life forms showed that terophytes prevailed several times over hemicryptophytes and cryptophytes (Fig. 3). The characteristic feature of weed socio-ecological groups was based on the occurrence of syntaxonomically welldefined species (Table 1). Four main socio-ecological groups were distinguished. The first one comprised plants characteristic for the Stellarietea mediae class. They were not tied to a specific crop type but grew on fields subjected to certain cyclical agricultural treat-

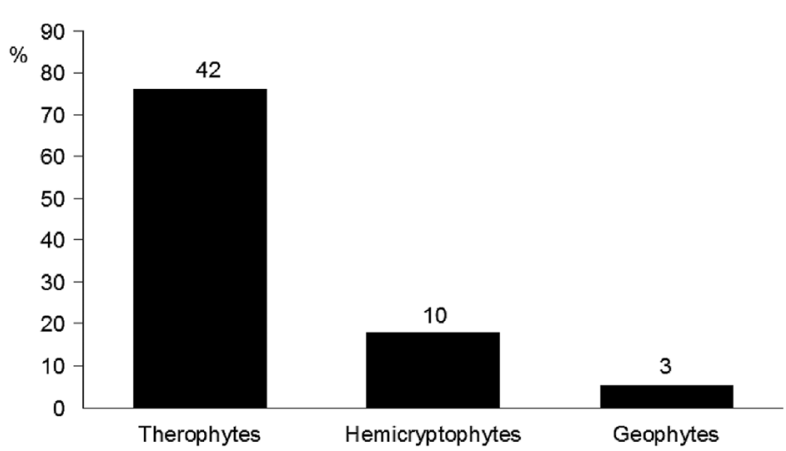

Fig. 3. Share of life forms

ments. 13 species belonged to this group, the most abundant in diaspores among them were: Polygonum persicaria, Fallopia convolvulus and Anthemis arvensis. A subsequent group of 16 species was composed of weeds of winter crops characteristic for the order Centauretalia cyani, with Apera spica-venti, Bromus secalinus, Spergula arvensis and Vicia tetrasperma richest in diaspores:. The third group was made up of weeds of root and orchard crops with a short life cycle (Polygono-Chenopodietalia). They developed after harvesting the spring crop and grew until the autumn harvest. Here, 12 species were found with Chenopodium album prevailing, followed by Raphanus raphanistrum and Vicia cracca. Group 4 included mainly ruderal plants from the Artemisietea vulgaris class with the taxa characteristic for the mosaic of areas, such as fresh or wet meadows of Molinio-Arrhenatheretea class, ecotones - Trifolio Geranietea sanguinei, edges of ditches or ponds - Bidentetea tripartiti and Agropyron-Rumicion crispi. The proceeding analyses led to reconstruction of edaphic conditions that prevailed on the rye field. They were formed by a variety of soil-forming processes resulting from the diversity of geographical and natural environment in a given period. The natural environment and the soil were excellent media capturing information about direct and indirect anthropogenic impact on the habitat (Degórski 2005). The analysis of edaphic preferences of rye weeds based on ecological indicator values showed that in Pomorzany mostly fresh, neutral soils, moderately poor in nutrients and rich in nutrients prevailed (Fig. 4). Some plants, including Chenopodium album or Echinochloa crus-galli, preferred soils rich in nitrogen which could prove fertilization of fields with manure. Other taxa with unique habitat preferences also occurred. Spergula arvensis, Rumex acetosella or Digitaria sanguinalis were found growing mostly on poor and acid soils. Setaria pumila, Valerianella dentata, Galeopsis ladanum, Camelina microcarpa or Galium spurium - were cultivated on dry and moderately poor in nutrients soil. Polygonum mite and P. hydropiper that 


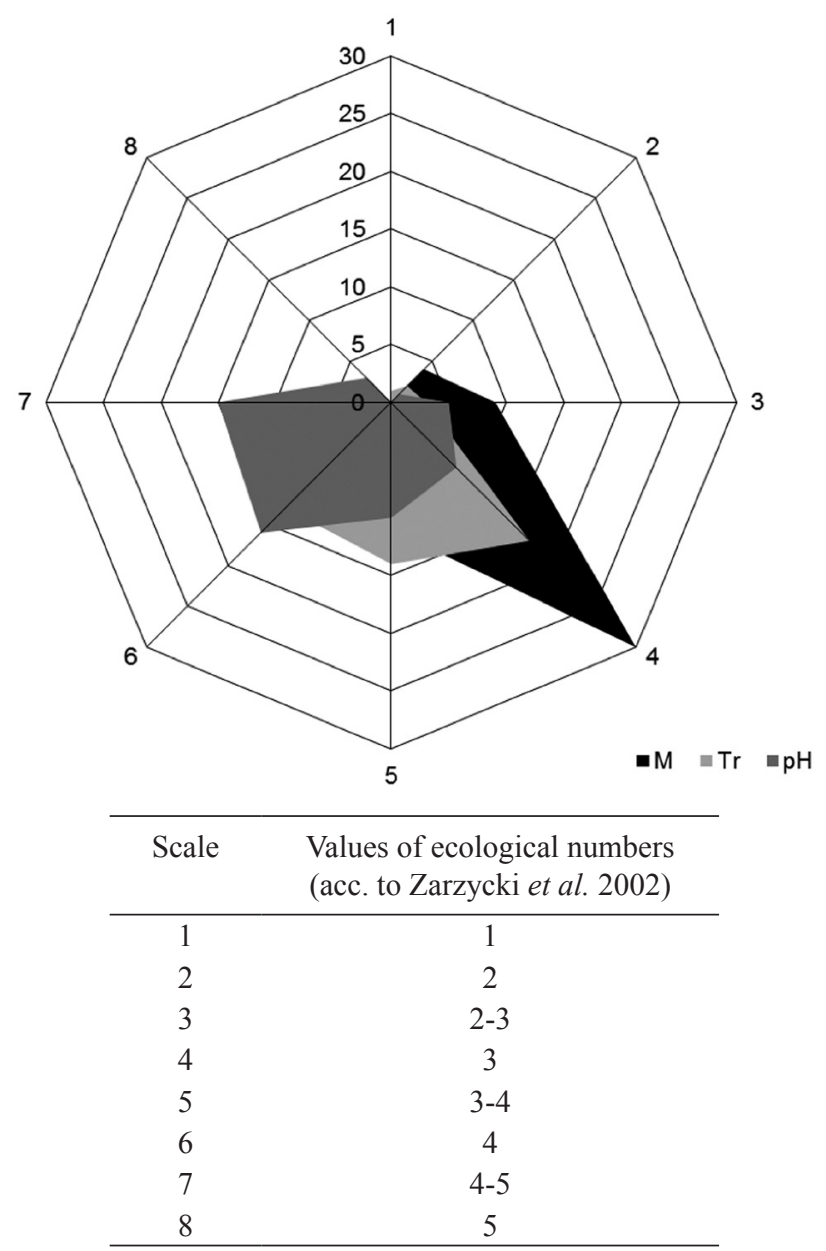

Fig. 4. Habitat preferences of weeds based on ecological numbers Explanations: $\mathrm{M}$ - moisture, $\mathrm{Tr}$ - trophy, $\mathrm{pH}$ - soil acidity

colonized wet and watery soils proved the occurrence in the neighborhood of riverbanks. Polygonum aviculare indicated areas of disturbed surface layer - fuzzy and muddy areas of clay soils or treaded pathways.

\section{Discussion}

The authors assumed that the analyzed deposit of charred grain derived from a rye field that had been situated nearby the grange. It was presumably harvested in the same year or the previous year when the fire destroyed the building in which grain had been stored. The soil, as indicated by weeds, was neutral, moderately wet (fresh), from poor to rich in nutrients. Nowadays there are mainly podzols and pseudopodzols (fawn) in the neighborhood, classified as good wheat complex (group III) to poor rye complex (group IV). To the north and west of the site, there are fertile alluvial soils on the border of the Skrwa River (Zapaśnik 2013). Sowing rye on podzols was consistent with its requirements. It had considerable capacity to retrieve inaccessible nutrients from soil as well as tolerate $\mathrm{pH}$. The proper structure of soil had a beneficial effect on rye, whereas excessive humidity affected it negatively (Herse 1976; Mazurek et al. 1976). The main purpose of cultivation of Secale cereale was to obtain grain for making bread and providing animal feed (Herse 1976). Apart from rye, there were also barley, oats, wheat and buckwheat. According to historical sources, grain cultivation played a major role, and the most important was rye, then oats, barley and wheat. Relatively less important was the millet (Topolski 1964). In studies regarding crop deposits discovered at archaeological sites, the occurrence of the admixture of other cultivated plants is regarded as evidence of rotations (Strzelczyk 2003; Lityńska-Zając 2005). Barley was recorded in the analysed material in a large amount, so it could have been sown on this field in the previous year. In addition to the above mentioned cereals, numerous residues of common buckwheat were present in the material. Its seeds were rich in starch and protein, but due to their lack of gluten, they were not generally suitable for baking and were used for the preparation of porridge instead. In addition to its use as food, it could also be used as forage for animals. The origins of buckwheat cultivation were formerly linked to the Tatar invasions in the $13^{\text {th }}$ century. However, the 
oldest finds of this species on Polish lands date back to the $9^{\text {th }}$ century (Wasylikowa 1978; Alsleben 1995). Its proliferation did not occur until Middle Ages and the modern times (Lityńska-Zając 2005). The accumulation of common buckwheat residues in archaeological stands are rare (cf. Badura 1999). It was usually discovered only as a single seed. Numerous remains of buckwheat represented in the deposit of the Pomorzany farm, therefore, deserve special attention. Also 6 seeds of Tartary buckwheat (Fagopyrum tataricum (L.) Gaertn.) considered to have the center of origin in uplands and mountain region of either central and western China or northern India (Ohnishi 2004) were recorded. It is nowadays recognized as a weed of cereal and oil seed crops. Its status as a crop plant in historical times in Poland has not yet been categorically recognised. Even in ethnobotanical studies it is difficult to find traces of use of Tartary buckwheat, because the name "tatarka" was used for common buckwheat and, according to Köhler (2013), the farm people did not distinguish between these two species. Other commonly grown species were oil plants, such as hemp and flax. They were sown particularly often on peasant farms and in gardens, but on the granges they played a much less important role (Topolski 1964). Both of these species were sown as spring crops. Because of their properties, they were not only used as plants for the production of oil but also as a raw material in textile industry.

Large collection of diaspores of wild plants made it possible to conduct a series of analyses regarding economical-environmental importance. In Poland, since the Iron Age, cereal communities developed similarly to the present ones (Lityńska-Zając 2005). Based on ecological requirements of individual species and their occurrence in modern and relict plantings, there is a high probability of restoring former agronomic practices (Wasylikowa 1983; Lityńska-Zając 2005). Weed species contaminating field crops in Pomorzany included, among others: Agrostemma githago, Raphanus raphanistrum, Apera spica-venti, Bromus secalinus, Centaurea cyanus, Spergula arvensis, Thlaspi arvense, Viola arvensis/tricolor, Fallopia convolvulus, Polygonum persicaria, Mentha arvensis, Anthemis arvensis, Papaver rhoeas, Rumex acetosella, Scleranthus annuus, Aphanes arvensis, Setaria pumila and S. viridis/verticilata. They were mostly annual species. They could grow both among spring and winter crops, but weeds which preferred winter crops prevailed. Weeds characteristic for root crops and gardens were less marked. In earlier periods of history - since the Neolithic Age - weeds regarded now as characteristic for root crops, were probably growing in fields of millet, peas, broad beans, horticulture plants and spring crops. They could also grow in cereals sown in clumps or rows. Their presence was directly associated with a small canopy density (Lityńska-Zając 2005). These weeds in the analyzed rye field occurred in the environment analogous to nowadays, so it can be regarded as evidence for the cultivation of the common species of root crops in proceeding years. The presence of a certain taxa such as: Mentha arvensis, Rumex acetosa, $R$. acetosella, $R$. obtusifolius, $R$. crispus, Plantago lanceolata or Pimpinella saxifraga which belonged to perennials, indicates that rye was cultivated on set-aside fallow (cf. Wasylikowa 1983). Among the remaining taxa, we found plants whose diaspores could have originated from other areas adjacent to the field of rye. A nearby mosaic of habitats could, therefore, have an impact on the appearance of these species in cultivation. For example Rumex acetosa, Plantago lanceolata or Vicia cracca seem to indicate that fresh meadows were in the vicinity; Polygonum hydropiper, P. mite, P. lapathifolium - point to the location of the crops near the fertile banks of the Skrwa River or field drainage ditches; Coronilla varia - that at the edge of the field, a forest planting could be present.

\section{References}

Alsleben A. 1995. Nutzpflanzen aus dem mittelalterlichen Wolin. Zwei ausgewählte Gruppen: Getreide Und Lein. Offa 52: 185-217.

Badura M. 1999. Szczątki gryki (Fagopyrum esculentum Moench) ze średniowiecznego Kołobrzegu. Polish Botanical Studies, Guidebook 23: 219-231.

Badura M. 2011. Rośliny użytkowe w dawnym Gdańsku. Studium archeobotaniczne. 337 pp. Wyd. Uniwersytetu Gdańskiego, Gdańsk.

DEGóRSKi M. 2005. Gleba jako indykator zmian w środowisku przyrodniczym. Przegląd Geograficzny 77(1): 337354.

Goslar T. 2013. Pomorzany - Raport z wykonania datowania C-14 - jama 318. In: T. Poklewski-Koziete T. (ed.).
Centrum włości szlacheckiej w Pomorzanach i Pomorzankach pod Kutnem od 1375 do 1810 roku. CD-room, Łódź.

Herse J. (ed.). 1976. Szczegółowa uprawa roślin. 609 pp. PWN, Warszawa.

JACKOWIAK B. 1993. Atlas of distribution of vascular plants in Poznań. Publications of the Department of Plant Taxonomy of the Adam Mickiewicz University in Poznań 3: 1-409.

Kosina R. 1977. Wrocławskie spichrze z XI w. - przyczynek do badań nad gospodarką regionu. Kwartalnik Historii Kultury Materialnej 25: 257-267.

KoszalKa J. \& StrzelczYK J. E. 2006. The grain storehouse from the early medieval stronghold at Józefów 
near Kalisz. Fasciculi Archaeologiae Historicae 18: 9-18

KöHLER P. 2013. Odpowiedź Romana Gutwińskiego (18601932) na ankietę etnobotaniczną Józefa Rostafińskiego (1850-1928) ogłoszoną w 1883 r. Etnobiologia Polska 3: 47-53.

LiTYŃSKA-ZAJĄC M. 2005. Chwasty w uprawach roślinnych w pradziejach i wczesnym średniowieczu. 444 pp. Wyd. Instytutu Archeologii i Etnologii PAN, Kraków.

LityŃSKa-ZajĄC M. \& Wasylikowa K. 2005. Przewodnik do badań archeobotanicznych. In: J. B. FALIŃSKI (ed.). Vademecum Geobotanicum, 5, 566 pp. Sorus, Poznań.

Maik 2013. Zabytki nieruchome. In: T. PoKLEwski-KozIEŁe (ed.). Archeologiczne zeszyty autostradowe Instytutu Archeologii i Etnologii PAN. Centrum włości szlacheckiej w Pomorzanach i Pomorzankach pod Kutnem od 1375 do 1810 roku. 14: 43-50. Łódź.

Matuszkiewicz W. 2001. Przewodnik do oznaczania zbiorowisk roślinnych Polski. In: J. B. FALIŃSKI (ed.). Vademecum Geobotanicum 3, 537 pp. Wyd. Nauk. PWN, Warszawa.

Mazurek J. \& Ruszkowski M. 1976. Żyto. In. J. Herse (ed.). Szczegółowa uprawa roślin, pp. 78-98. PWN, Warszawa.

Mirek Z., Pięroś-Mirkowa H., Zając A. \& Zając M. 2002. Flowering plants and pteridophytes of Poland. A checklist. In: Z. MiReK (ed.). Biodiversity of Poland, 1, 442 pp. W. Szafer Institute of Botany, Polish Academy of Sciences, Kraków.

Ohnishi O. 2004. Origin of Cultivated Buckwheat. Proceedings of the $9^{\text {th }}$ International Symposium on Buckwheat, pp. 16-21.

RALSKI E. 1957. Szczegółowa uprawa roślin. 735 pp. PWRiL, Warszawa.
Strzelczyk J. 2003. Proso zwyczajne (Panicum miliaceum L.) we wczesnym średniowieczu Wielkopolski Prace Zakładu Biogeografii i Paleoekologii UAM w Poznaniu, 2: 1-36. Bogucki Wyd. Nauk., Poznań.

Topolski J. 1964. Polowa produkcja roślinna. In: B. BARANOWSKI \& J. TOPOLSKI (eds.). Zarys historii gospodarstwa wiejskiego w Polsce. Okres gospodarki folwarczno-pańszczyźnianej (od drugiej połowy XV do XVIII w.). 2(4): 146-178. Warszawa.

Tymrakiewicz W. 1962. Atlas chwastów. 367 pp. PWRiL, Warszawa.

Wasylikowa K. 1978. Plants remains from Early and Late Medieval time found in the Wawel Hill in Cracov. Acta Palaeobotanica 19(2): 1-198.

Wasylikowa K. 1983. Antropogeniczne zmiany roślinności w holocenie. In: J. K. KozŁowsKi \& S. K. KozŁowsKI (eds.). Człowiek i środowisko w pradziejach, pp. 5372. Warszawa.

ZAJĄC E. U. \& ZAJĄC A. 1975. Lista archeofitów występujących w Polsce. Zeszyty Naukowe UJ, 395, Prace Botaniczne 3: 7-16.

ZAPAŚNIK T. 2013. Obraz geomorfologiczny. In: T. PoKlewSKi-Kozięl (ed.). Archeologiczne zeszyty autostradowe Instytutu Archeologii i Etnologii PAN. Centrum włości szlacheckiej w Pomorzanach i Pomorzankach pod Kutnem od 1375 do 1810 roku. 14: 17-23. Łódź.

ZARZYCKi K., TrZciŃSKa-Tacik H., RÓŻAŃSKi W., SZeląG Z., WoŁeK J. \& KorZeniaK U. 2002. Ecological indicator values of vascular plants of Poland. In: Z. MireK (ed.). Biodiversity of Poland, 2, 183 pp. W. Szafer Institute of Botany, Polish Academy of Sciences, Kraków. 